\title{
Does ownership structure affect dividend policy? A panel data analysis for the French market
}

\author{
Wissem Daadaa* \\ FSEG de Nabeul, \\ Campus Universitaire Mrezga, \\ Route Hammamet, 8000, Nabeul, Tunisia \\ Fax: +216-72-232-318 \\ Email: wissem.daadaa@yahoo.fr \\ *Corresponding author
}

\section{Fathi Jouini}

Faculty of Economic and Management of Sousse,

University of Sousse,

Riadh city, 4023, Sousse, Tunisia

Email: fathi_75@hotmail.fr

\begin{abstract}
This study tries to examine the effect of ownership structure on the dividend policy of 102 French companies listed on the SBF $120^{1}$ index for a period of five years from 2010 to 2014 with a total of 510 observations. Based on agency and signal theories, we have empirically demonstrated the role of substitution between corporate governance mechanisms and dividend payout. Our study also demonstrates the role of dividend policy in disciplining manager behaviour (or in reducing managers' opportunistic behaviour). Our results indicate that firms with institutional, largest, managerial and family shareholders pay lower dividends.
\end{abstract}

Keywords: ownership; payout; dividend yield.

Reference to this paper should be made as follows: Daadaa, W. and Jouini, F. (2018) 'Does ownership structure affect dividend policy? A panel data analysis for the French market', Int. J. Governance and Financial Intermediation, Vol. 1, No. 1, pp.18-36.

Biographical notes: Wissem Daadaa is a Doctor in Finance and a Professor Assistant in the University of Tunis. He teaches finance and accounting. He participates to several international conferences in finance and he is an author of several papers published in international reviews.

Fathi Jouini is an assistant at the Sousse University. His research interests include corporate governance, earning quality, corporate finance, and credit risk. He has published many articles in peer-reviewed journals: Journal of Asset Management, Afro-Asian Journal of Finance and Accounting, Mediterranean Journal of Social Sciences, Journal of Economic and Social Studies, International Business Research, and International Journal of Economics and Financial Issues. 


\section{Introduction}

Financial literature has always analysed agency conflicts between managers and shareholders due to a separation between ownership and firm control. Recent empirical studies have shown that companies with large shareholders confront a conflict between majority and minority shareholders (Jong et al., 2011).

Pound (1988) considers that manager's ownership structure affects firm dividend behaviour. The issue of dividend policy has been widely discussed in the financial literature (Miller and Modigliani, 1961). The objective is to know the different elements that can guide the choice of companies in the dividend payout. Also, the dividend is always considered as a guarantee for the majority and minority shareholders and limits the expropriation of minority shareholders.

According to Gugler and Yutoglu (2003), a high dividend payment, optimally limits the private profits taken by insiders and therefore the expropriation hypothesis will be limited. To distinguish the hypothesis of expropriation from the cash flow hypothesis, some authors such as Bebchuk et al. (2000) analyse the ownership and control structure of firms and conclude that these factors affect the dividend distribution policy.

In a financial market, the ownership structure is very varied and each shareholder may have different interests in his participation in the corporate capital. According to Allen et al. (2000), institutional investors prefer to receive higher dividends. Minority shareholders with short-term objectives also prefer a high dividend (Jain, 2007). On the other hand, firms with a high level of concentration tend to pay less dividends (Jensen et al., 1992).

Shleifer and Vishny (1997) argue that majority shareholders prefer to generate private profits from the company and reduce the paid dividends. This divergence of interests invites us to understand the influence of the nature of the shareholders in corporate decisions taking regarding the dividend policy. The purpose of this study is to analyse the role of the ownership structure as an explanatory factor for dividend levels in a developed country such as France.

Our study focuses on the analysis of the relationship between ownership structure and dividend policy of companies listed on the SBF120 index. The research sample consisted of 510 observations from 2010 to 2014. The results obtained show a negative and significant relationship between the dividend policy and the variables of ownership structure (ownership concentration, institutional ownership and family ownership). The rest of the paper will be organised as follows: Section 2 examines the literature review, Section 3 focus on the presentation of the hypotheses, then we analyse the results and finally the conclusion.

\section{Literature review}

\subsection{Ownership structure and the dividend policy}

Several studies have focused on the dividend distribution policy; they attempt to research the factors determining the dividend distribution policy. The ownership structure seeks to analyse the characteristics related to the nature and identity of shareholders structures. Recently, several studies have attempted to establish the links between ownership 
structure and dividends policy. They consider that company's dividend policy signal the future firms profits for investors (Miller and Rock, 1985).

Fama (1974) and Jensen and Meckling (1976) proposed the agency theory of dividend policy, proving the relationship between the dividends distribution and agency cost. Shleifer and Vishny (1986) found a positive relationship between ownership structure and dividends.

According to Burkart et al. (1997), dividend policy is influenced by the ownership and control structure and is determined by ownership concentration of firms. Chen and Steiner (1999) found that managerial ownership helps to resolve agency conflicts between shareholders and managers, but accentuates the agency conflict between shareholders and bondholders.

Short et al. (2002) analyse the relationship between ownership structures and the dividend policy. They analysed the relationship between institutional ownership and dividends and found a positive relationship between dividend distribution policy and institutional ownership. Wie et al. (2003) observed that there is a significant positive correlation between ownership structure and cash dividends.

Hofler et al. (2004) concluded that institutional ownership is not statistically related to dividends distribution. Stouraitis and $\mathrm{Wu}$ (2004) studied the effect of ownership structure on the dividend policy of Japanese firms and showed that the effect of managerial ownership and bank ownership on dividends is positive, especially for the small companies.

Renneboog and Trajanowski (2005) conclude that concentrated-ownership firms tend to opt for dividends rather than share repurchase. However, Naceur et al. (2006), who conducted their study on Tunisian firms, reported that the ownership concentration had no impact on a company's dividend policy. In another study, Mollah et al (2007) measured the effect of insider ownership, shareholder dispersion, free cash flow on the dividend payout ratio and documented that agency costs have a negligible effect on the behaviour of a company's dividends.

Kim et al. (2008) attempted to investigate the effect of corporate governance and the dividend policy of Korean companies and found that firms with financing constraints tend to decrease dividends, with an improvement in their corporate governance.

Kouki and Guizani (2009) conclude a negative relationship between dividends and ownership concentration. Sharif et al. (2010) have shown that there is a significant positive correlation between institutional ownership and the dividend payout ratio, while the relationship between dividend and individual ownership is negative. In addition, the ownership concentration, measured by the top five shareholders, affects positively the dividend payout ratio.

Afza and Mirza (2010) study the impact of firms characteristics on dividend policy in Pakistan and found that managerial ownership, individual ownership, cash flow and size are a significant determinants of dividend behaviour. Gill and Obradovich (2012) have established that the decision to pay dividends is a positive function of the board, size, duality of the manager, and firm's internationalisations, and a negative function of institutional ownership.

The conclusion of the Yarram (2011) study implies that firms with independent board contribute to improving governance through a strong disciplinary role and a dividend oversight role. Harada and Nguyen (2011) found that the dividends payout is negatively related to the ownership concentration. 
Abdullah et al. (2012) found that ownership concentration is the only form of ownership that affects dividend policy. Similarly, Warrad et al. (2012) found a positive and significant relationship between the ownership structure and the dividend distribution policy, however, Gharaibeh (2013) found a negative relationship between managerial ownership and dividend policy. Moreover, Nawaiseh (2013) confirmed that insider ownership has a negative impact on dividends payout while the ownership structure is positively related to the dividend policy.

Firth et al. (2016) investigates the effects of mutual funds, on firms' dividend payouts in China financial market. They find that mutual funds oblige firms to pay higher cash dividends. They find that the mutual funds' effects are stronger in long investment horizon and large ownership interest. Lin et al. (2017) analyse the relationship between dividend policy and ownership structure in Chinese financial market. They conclude that firms with higher information asymmetry are less likely to pay dividends and that state-controlled firms with higher information asymmetry would pay higher dividends compared to others firms.

Gonzalez et al. (2017) examine the effect of ownership concentration on dividend policy using a sample of firms based in six Latin American countries. They find that firms, with high concentration and individual large ownership, pay fewer dividends. Balachandran et al. (2017) consider that insider ownership is positively associated to the decision to pay dividends and this effect does not vary between traditional and imputation tax systems. Firms with higher foreign institutional ownership are less likely to pay dividends and have lower payout ratios.

\subsection{Shareholders and dividend policy}

The above development clearly shows that agency cost is one of the determinants of the firm's dividend payout. However, these agency costs are specific to each firm and are based on the ownership structure. Alli et al. (1993) argue that agency problems intensify if the number of shareholders is important. If dividends can alleviate agency problems, then there is a positive relationship between the shareholders number and the dividend distribution rate.

Agrawal and Mandeleker (1990) suggest that the ownership concentration generate an effective control of shareholder management. Indeed, when ownership structure is dispersed, none of the owners has an incentive to invest in the control of the managers because it will alone bear the cost while all the shareholders will benefit from this action.

The agency theory shows that the presence of informed shareholders is a very important factor to ameliorate corporate governance. As a result, the disciplinary power of the director's board can be expected to be low in companies with concentrated ownership. In this sense, Fernandez and Arrondo (2005) found a negative relationship between the ownership concentration and duality between firm director's and president of board. They conclude that informed shareholders are a very important factor to ameliorate corporate governance. Institutional investors influence and control the firm management, and contribute to determinate the dividend policy.

According to Aguenaou et al. (2013), institutional investors exert pressure to pay high dividends in order to reduce agency costs. Indeed, Allen et al. (2000) have shown that firms with institutional investor ownership have a high dividend level; they find a 
positive relationship between institutional investors and dividends. Institutional or financial investors play active role on corporate governance.

McConnell and Servaes (1990) suggest that leadership roots would be more difficult with the existence of institutional investors. Therefore, in the presence of institutional owners, the company is less likely to use dividends to reduce agency costs. Similarly, many studies have shown that institutional investors have a positive impact on agency problems by reducing agency costs and influencing dividend policies (Han et al., 1999).

Individual shareholders who are actually insiders seek to impose low dividend policies in order to increase the cash flow available. The literature finds a negative relationship between dividends payout and individual ownership. The results, however, differ in terms of their implications for the firm's efficiency ratio and their participation on firm capital.

\subsection{Ownership structure, dividend and financial theories}

\subsubsection{Agency theory}

Jensen and Meckling (1976) consider that the agency relationship occurs when the informed shareholders engage directors to perform firms on their behalf. The agency cost arises from the fact that interests between shareholders and management are contradictory. Then, the manager will benefit from the additional dividends. This will have negative implication on the shareholders interests.

Subsequently, Jensen (1986) suggested that the dividends payment create conflicts between managers and shareholders because managers would reduce dividend payment to hold resources. On the other hand, shareholders prefer dividends to retained earnings. If firms reduce dividend payment, managers may commit resources to unprofitable projects. Consequently, the conflict of interest arises amongst them, which can be resolved by the dividend distribution.

Rozeff (1982) consider that dividend payment reduce agency costs. Dividend policy plays a crucial role in reducing agency costs and reduces conflicting interests. Jensen and Meckling (1976) argue that the interest divergence between shareholders and managers are more important in presence of the manager's shareholders. They seek to maximise their personal wealth by opportunistic behaviour that is detrimental to the firm patrimony.

\subsubsection{Theory of signalling}

The signalling theory considers that managers drive information about firm performance to shareholders in order to create a credible relationship. Managers have more information about firm than investors, but they are still reluctant to provide transparent information to shareholders. Thus, the dividend policy can be used as a signal for the firm future prospects. Li and Zhao (2008) have shown that dividend policy plays an important role because it can be used to transmit information to shareholders about the firm value.

\subsubsection{The cash flow theory}

Lim Hua Min shows that the best test of governance is paying dividends. "The agency conflict affects the dividend policy between shareholders and managers because of overinvestment problems" (Sawicki, 2005). Agency conflicts play two roles: The first allows shareholders to control manager. Allows manager to show that they are making 
sure to maximise the wealth of shareholders and ensure regular payment of dividends, and any dividend reduction would be perceived as a sign of mismanagement.

Easterbrook (1984) presented two reasons to distribute dividends: The first reason is that conflicts between shareholders and managers generate two types of costs: controlling costs borne by shareholders and risk aversion. Indeed, when the manager invests his human capital in the company, adverse risk increase. However, shareholders are concerned with non-diversifiable risk because they can diversify their portfolios. In this case, the manager will choose the least risky projects, even if they are less profitable for the shareholders.

The manager control debt risk ratio by using an appropriate dividend policy, he finances his investment projects by retaining profit and debt in order to reduce the risk. However, financing investments by debt causes the wealth transfer from shareholders to creditors. The second reason is that dividends are pushing managers to finance their investment projects by financial market. Jensen (1986) indicates that shareholders are encouraged to monitor dividend when the company is in an over-investment situation. Consequently, dividends increase will be favourably received if the firm has no potential growth, it will have the ability to reduce the risk of overinvestment by minimising free cash flow. So, a dividend reduction with low growth opportunities is considered as bad news. Shareholders see that dividends could reduce the mangers willingness to increase cash flow and invest in future projects to serve their own interests.

Lie (2000) showed a positive relationship between free cash flow and increased dividends. Specifically, the author stated that companies have a tendency to distribute extraordinary dividends or to make public offers in the case of non-recurring surplus funds. However, if companies have recurring surplus funds, they will use an increase in ordinary dividends.

Dividends are then paid when companies try to establish a status to have a good treatment of shareholders. Therefore, the dividend policy acts as a monitoring mechanism for the company. Borokhovich et al. (2005) confirmed the hypothesis that dividend distribution reduces agency conflicts by showing that, on average, firms with large independent member in the board experience aggressive revenue declines as a result of an increase in dividends. In companies that are characterised by low growth, shareholders delegate more authority to managers to encourage them to pay dividends rather than keep money and extract private profits.

\section{Hypotheses}

Concentration is a corporate governance mechanism that provides the largest shareholder with control over the firm. The presence of a large shareholder may lead to an agency conflict with minority shareholders. The majority shareholders may expropriate the minority shareholders (Morck et al., 1988) and exhaust the resources of minority shareholders (Short, 1994).

Agency problems increase as a result of the presence of ownership. These problems have a negative impact on the performance of the firm, leading companies to pay lower dividends. According to Maury and Pajuste (2002), the presence of a shareholder having more than half of the control of the firm has a negative effect on the payout rate. Some studies confirm this finding such as Mancinelli and Ozkan (2010) and Harada and 
Nguyen (2011) for Japanese companies. Gonzalez et al. (2017) examine the effect of ownership concentration on dividend policy using a sample of firms based in six Latin American countries. They find that firms, with high concentration and individual large ownership, pay fewer dividends. From this review we anticipate a negative relationship between the dividend distribution and concentration of ownership.

$\mathrm{H}_{1}$ There is a negative relationship between ownership concentration and dividend policy.

Institutional investors have the necessary resources and can exercise the control function effectively. The monitoring roles of institutional investors on corporate financial policies precisely dividend payout decision is examined by some authors such as Crane et al. (2016) and Kouki and Guizani (2009). The results of the relationship between dividend payout and institutional investor are mixed. The study of Grinstein and Michaely (2005) indicate that institutional investors seek to influence firms in order to increase the dividend payout. They avoid to invest in companies with higher dividend payout or without dividends. Others studies have found a negative relationship between institutional ownership and the dividend payout ratio, demonstrating the substitution role between dividend policy and the presence of institutional investors (Kouki and Guizani, 2009).

$\mathrm{H}_{2}$ There is a negative relationship between institutional ownership and dividend policy.

Corporate family is characterised by the presence of management and ownership for the same person. The exercise of both tasks by the same person can help to minimise agency problems (Izmen, 2003).

The presence of a family concentration can have strong initiatives to expropriate the wealth of minority shareholders, which will increase conflicts.

Under these conditions, families opt for the lower dividend payout to maintain the cash flows and they can expropriate to the minority shareholders. In this case, we anticipate a negative link between family ownership and the dividend payout.

According to Shleifer and Vishny (1986), this monitoring generally substitutes the distribution of liquidity. Several studies show a negative influence on the rate of dividend payout of the first shareholder's control level (Hu and Kumar, 2004; Maury and Pajuste, 2002) or the concentration of ownership (Rozeff, 1982; Dempsey and Laber, 1992).

Studies on the dividends payout of French family firms confirm the results: Hirigoyen (1984) shows that it is very low in unlisted family firms and, according to Calvi-Reveyron, listed family firms pay less than non-family firms.

Similarly, Gugler (2003) shows that Austrian family firms have a significantly different dividend policy than non-family firms. If these results are in the direction of a substitution between dividend payout and supervision by large shareholders, they may also be evidence of expropriation of minority interests by a controlling shareholder.

According to Maury and Pajuste (2002), the presence of a shareholder with more than half the control of the firm has a negative effect on the dividend payout rate. They also show that a non-controlling family control shareholder has a favourable effect on the dividends payout, whereas if it is a manager, this negatively affects the dividends payout. Mulyani et al. (2016) analyses the roles of dividends and leverage to mitigate agency problems using a sample of family firms in Indonesia. They find a significant negative association between family ownership and dividend payout and a negative relation 
between dividend payout and leverage. They conclude that family firms prefer lower dividend pay-out and higher leverage.

$\mathrm{H}_{3}$ There is a negative relationship between family ownership and dividend policy.

According to agency theory, dividend payout helps to discipline leadership behaviour. The dividend payout can act as a control mechanism. Some studies have shown the dividends payout is widely used by firms when the conflict between the manager and the shareholder is very important. According to Rozeff (1982), firms that participate in management pay less dividends. According to this author, dividends may encourage managers to avoid investment with negative net present value on internal funds.

The results of Moh'd et al. (1995) and Holder et al. (1998) confirm this negative relationship between dividends and management ownership. Gugler and Yurtoglu (2003), for a sample of German companies, found a negative relationship between largest shareholders and dividend changes.

For a sample of 37 countries, Truong and Heaney (2007) indicate the dividend payout is lower when there is largest shareholders and in the same time insiders. In this situation, the insiders may impose lower dividend policies in order to increase the cash flow at their discretion.

$\mathrm{H}_{4}$ Relationship between managerial ownership and dividend payouts are negative.

\section{Presentation of the sample and variables}

\subsection{Sample presentation}

Our sample is composed of 102 French companies listed on SBF120 for a period of five years from 2010 to 2014. The choice of the period is explained by the presence of the achieved improvement in French corporate governance and the new adopted measures. At the end of the $2000 \mathrm{~s}$, there new regulation related to corporate governance and financial security. These laws seek to ensure the interests of shareholders. Other laws have been proposed regarding public offerings such as the law of new economic regulations and the directive of the European Parliament. All these regulations can lead to a change in ownership structure and its effect on the corporate financial policy.

Table 1 Sample presentation

\begin{tabular}{lcc}
\hline Code & Industry & Number of firms \\
\hline 10 & Energy & 4 \\
15 & Materials & 8 \\
20 & Industrial & 19 \\
25 & Consumer discretionary & 14 \\
30 & Consumer staples & 2 \\
35 & Health care & 22 \\
45 & Information technology & 31 \\
50 & Telecommunication services & 2 \\
& Total & 102 \\
\hline
\end{tabular}


In our sample, we eliminate financial institutions that have specific regulations as well as companies with missing data. Our sample is composed of companies eight different industry sectors. The accounting and financial data have been extracted from the database compustat global. The corporate governance data were collected manually from reference documents and annual reports of French listed firms downloaded from the $\mathrm{AMF}^{2}$ website.

\subsection{Presentation of variables}

To study the relationship between the dividend policy and ownership structure, we chose two dependent variables dividend payout ratio and dividend yield.

The ownership structure is approximated by family, managerial, institutional ownership and the presence of majority shareholder.

For control variables, we used two variables related to the board of directors, namely board size and frequency of board meeting. The other control variables concern the corporate specific characteristics.

$$
\begin{aligned}
& D I V Y_{i, t}=\alpha_{0}+\alpha_{1} F A M_{i, t}+\alpha_{2} M A N G_{i, t}+\alpha_{3} M A J_{i, t}+\alpha_{4} I N S T_{i, t} \\
& +\alpha_{5} B M_{i, t}+\alpha_{6} B_{S I Z E_{i, t}}+\alpha_{7} M T B_{i, t}+\alpha_{8} R O A_{i, t}+\alpha_{9} L E V_{i, t} \\
& +\alpha_{10} F S I Z E_{i, t}+\alpha_{11} F C F_{i, t}+\varepsilon_{i, t} \\
& D_{V I V} P_{i, t}=\alpha_{0}+\alpha_{1} F A M_{i, t}+\alpha_{2} M_{A N G_{i, t}}+\alpha_{3} M A J_{i, t}+\alpha_{4} I N S T_{i, t} \\
& +\alpha_{5} B M_{i, t}+\alpha_{6} B S I Z E_{i, t}+\alpha_{7} M T B_{i, t}+\alpha_{8} R O A_{i, t}+\alpha_{9} L E V_{i, t} \\
& +\alpha_{10} F S I Z E_{i, t}+\alpha_{11} F C F_{i, t}+\varepsilon_{i, t}
\end{aligned}
$$

DIVY notes dividend yield; DIVP indicates dividend payout ratio, it is total dividend divided by stock market capitalisation; FAM is the family ownership; $M A N G$ notes managerial ownership; MAJ is the concentration ownership; INST is the institutional investor ownership; $B M$ notes board meeting; BSIZE is the board size; MTB indicates market to book ratio; $R O A$ notes return on assets; $L E V$ is the leverage; FSIZE is firm size; $F C F$ indicates free cash flow.

\subsubsection{Dependent variable}

The measures used mostly by researchers (Mancinelli and Ozkan, 2010; Al-Najjar and Kilincarslan, 2016) are:

- The dividend yield which is measured by the ratio of the annual dividend paid divided by the market capitalisation.

- Another measure used by the authors namely the dividend distribution payout ratio which is approximated by the ratio between the amount of dividends and profits of the firm. This ratio is used by researchers to estimate future dividends and to calculate the retention ratio that allows the rate of future growth of profits.

\subsubsection{Independents variables}

These are the variables representing the characteristics of the ownership structure. Four variables were chosen to model the ownership structure: concentration of ownership, managerial ownership and the presence of institutional investors and family ownership. 
- Capital concentration (MAJ): the concentration of capital is an agency variable between shareholders and managers. It will be measured by the percentage of shares held by the major shareholders. This variable checks the substitution relationship between concentration of ownership and the dividend policy (Mancinelli and Ozkan, 2010).

- Managerial ownership (MANG): the managerial ownership is measured by the percentage of capital held by internal. This variable focuses on the separation between the two functions ownership and decision.

- Institutional ownership (INST): is measured by the percentage of capital held by bank, pension funds, and insurance. This proxy is used by Fairchild et al. (2014) and Al-Najjar and Kilincarslan (2016).

- $\quad$ The family ownership (FAM): is measured by the number of shares held by families in the firm capital. This variable is used by Chen et al. (2005), Yoshikawa and Rasheed (2010), Wei et al. (2011) and Al-Najjar and Kilincarslan (2016).

\subsubsection{Control variable}

- Firm size (FSIZE): This variable was used in the research of Al-Najjar and Kilincarslan (2016), Harada and Nguyen (2011), Mancinelli and Ozkan (2010) and Chen et al. (2005) as determinants of the dividend policy. In our research, we measure the firm size by the logarithm of stock market capitalization.

- Leverage ( $L E V)$ : The variable was used in the research of Pablo and Gonzalez (2010), Mancinelli and Ozkan (2010) and Al-Najjar and Kilincarslan (2016). It is expressed as the percentage of short-term and long-term debt by total assets. It is regarded as a control mechanism to align the interests of executives with those of shareholders and reduce conflicts between them. According to Jensen (1986) and Agrawal and Jayraman (1994), dividend policy and leverage are negatively related. According to them, the debt is an alternative to dividends to decrease agency costs related to free cash flow.

- Return on assets (ROA): The companies that generate profits distribute dividends. In agreement with the theory of signal companies report their profitability by increasing the dividend distribution (Al-Najjar and Kilincarslan, 2016). A positive relationship between the return on assets and the dividend policy is expected.

- Free cash-flow (FCF): This variable should be positively related to dividends. Free cash flow is defined as the sum of available excess liquidity after financing and investment in all projects with positive NPV (profitable projects). However, according to Jensen's (1986) study, a free cash flow situation can increase agency problems within the firm. According to Charreaux (1997), the existence of free cash flow allows managers to follow a diversification strategy in order to increase their discretion even if it is not profitable. The cash flow encourages the corporate to distribute dividends or repayment of its debts. In fact, limiting the problem of free cash flow depends on the effectiveness of corporate governance mechanisms such as the dividends payout. We anticipate a positive relationship between the FCF and the dividend policy. 
- Board size (BSIZE): The board of directors is a governance mechanism to control the executive. These members participate in decision-making in the interests of shareholders. This board of directors may not be effective if it is large in size. The inefficiency is explained by the lack of coordination between the different members (Jensen, 1993). This inefficiency affects the control task performed by the members of the board of directors. The firm pays dividends to discipline manger behaviour as a corporate governance mechanism. We anticipate a positive relationship between the dividend policy and the board size.

\section{$5 \quad$ Analysis and interpretation of results}

On the basis of descriptive statistics, we note that the average debt ratio of French companies is $18.5 \%$. Also, we note that on average the proportion owned by families in corporate is $16.45 \%$. The maximum family percentage is $77.28 \%$. The largest shareholder holds on average of $33 \%$. There are also companies owned by institutional shareholders. The boards of directors in French firms are composed of three to 20 members. On average these boards are composed of nine members which is a number suggested by some authors.

Table 2 Descriptive statistics

\begin{tabular}{lcccc}
\hline Variable & Mean & Std. dev. & Min & Max \\
\hline DIVP & 0.340 & 0.329 & -0.968 & 0.992 \\
DIVY & 0.033 & 0.029 & $7.23 \mathrm{e}-06$ & 0.256 \\
LEV & 0.186 & 0.132 & 0 & 0.744 \\
MTB & 1.261 & 2.905 & 0.024 & 54.492 \\
FAM & 0.165 & 0.245 & 0 & 0.773 \\
MAJ & 32.999 & 21.877 & 0.23 & 99.8 \\
INST & 35.573 & 27.511 & 0 & 99.999 \\
MANG & 3.797 & 9.016 & 0 & 68.27 \\
FSIZE & 6.208 & 2.374 & 1.507 & 11.523 \\
BSIZE & 9.261 & 3.863 & 3 & 20 \\
BM & 7.449 & 2.855 & 1 & 24 \\
ROA & -0.003 & 0.133 & -0.863 & 0.579 \\
FCF & -0.011 & 0.506 & -10.833 & 0.598 \\
\hline
\end{tabular}

Notes: DIVP: dividend payout ratio; DIVY: dividend yield; LEV: leverage;

MTB: market to book ratio; FAM: family ownership; MAJ: concentration ownership; INST: institutional investor ownership; MANG: managerial ownership; FSIZE: firm size; BSIZE: board size; BM: board meeting; ROA: return on assets; FCF: free cash flow. 
Table 3 Pearson correlation matrix

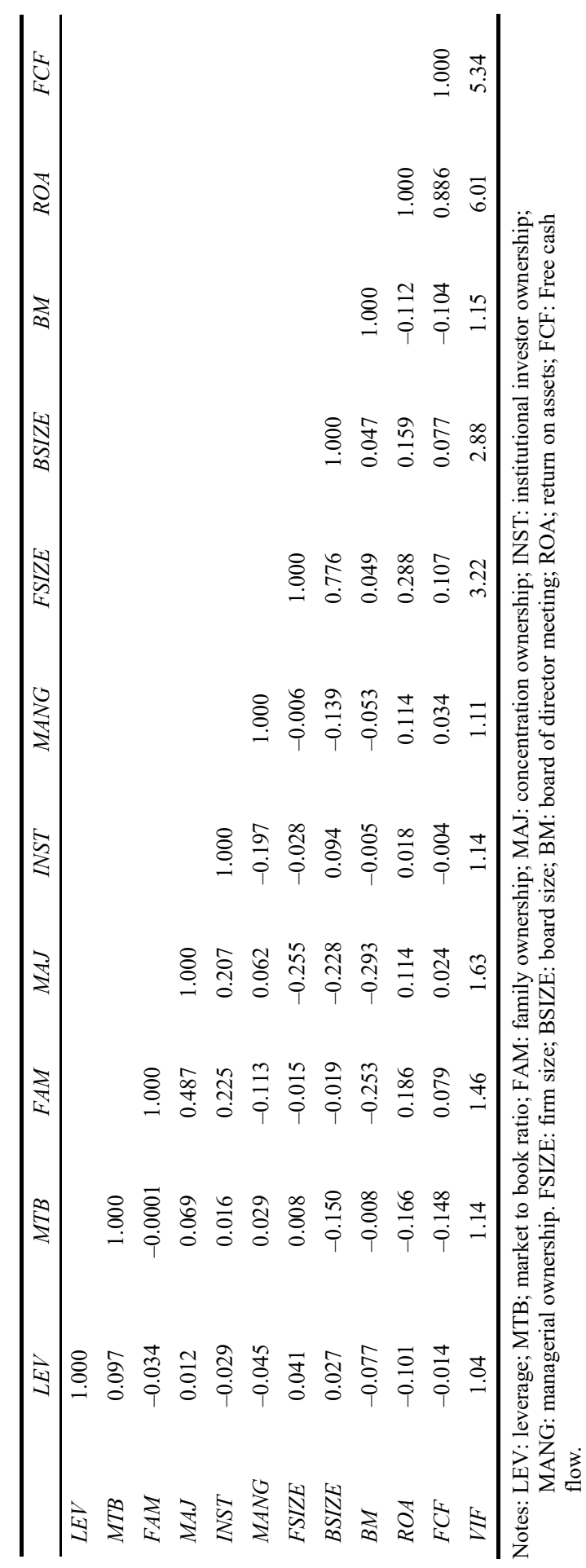


Our correlation matrix shows that there is a significant correlation between the size of the firm and the size of the board (0.77). Similarly, our results show a strong correlation between the return on assets and free cash flow (0.88). The multicolinarity test using the VIF test confirms the presence of correlation between the ROA variables; FCF; BSIZE; FSIZE. Taking into account this problem, we will estimate four equations for each dependent variable to have eight models at the end.

After the correlation analysis between the independent variables, we used the Hausman (1978) specification test. This test is a general test that can be applied to many specification problems in econometrics. Its most common application is the specification test of individual effects panel. It thus serves to discriminate fixed and random effects.

The probability of the test is less than $10 \%$, which implies that the fixed effects model is preferable to the random effect model. The result depends from the proxies of dividend policy. We also detected the presence of autocorrelation by using the Wooldridge test and heteroscedasticity based on modified Wald test.

After the correction of these two problems, we obtain the results provided by Table 4 .

There is a negative relationship between the growth opportunity measured by the market to book ratio and the company's dividend policy. This result is significant at the $1 \%$ level. Indeed the company that does not distribute dividends will reinvest it to finance its growth. We also found that the board size positively affects the dividend distribution policy and at a $10 \%$ level. Based on several empirical studies, it has been concluded that a large board of directors is less efficient than a small board, there will be a problem of coordination between the different members. In order to have a good control, dividend distribution can be used as a substitute mechanism to discipline managerial behaviour (La Porta et al., 2000).

Our results also show a positive effect of free cash flow on the dividend policy. Free cash flow which represents the sum of available excess liquidity after financing and investment can accentuate agency problems within the company. The existence of free cash flow allows managers to follow a diversification strategy to increase their discretion even if it is not profitable. The free cash flow allows the company to push the opportunities such as paying dividends. Dividend payout can discipline the manager behaviour.

Our results also indicate the positive relationship between return on assets and dividend policy. Indeed, the companies that generate the profits pay dividends. In agreement with the theory of signal firms report their profitability by increasing the dividend payout. This result is similar to the results of Al-Najjar and Kilincarslan (2016) for Turkish firms.

For the firm size, there is an ambiguity regarding the sign that depend on the measure used to approximate the dividend policy whether the dividend yield or the dividend payout.

For our independent variables, we found a negative relationship between managerial ownership and the dividend yield. This result is significant at a level of $10 \%$. The dividend acts as a corporate governance mechanism. It serves to discipline managerial behaviour and to reduce agency problems between the shareholder and the manager. When the manager is a shareholder, the company pays less dividends. 
Does ownership structure affect dividend policy?

Table 4 Relationship between dividend policy and ownership structure

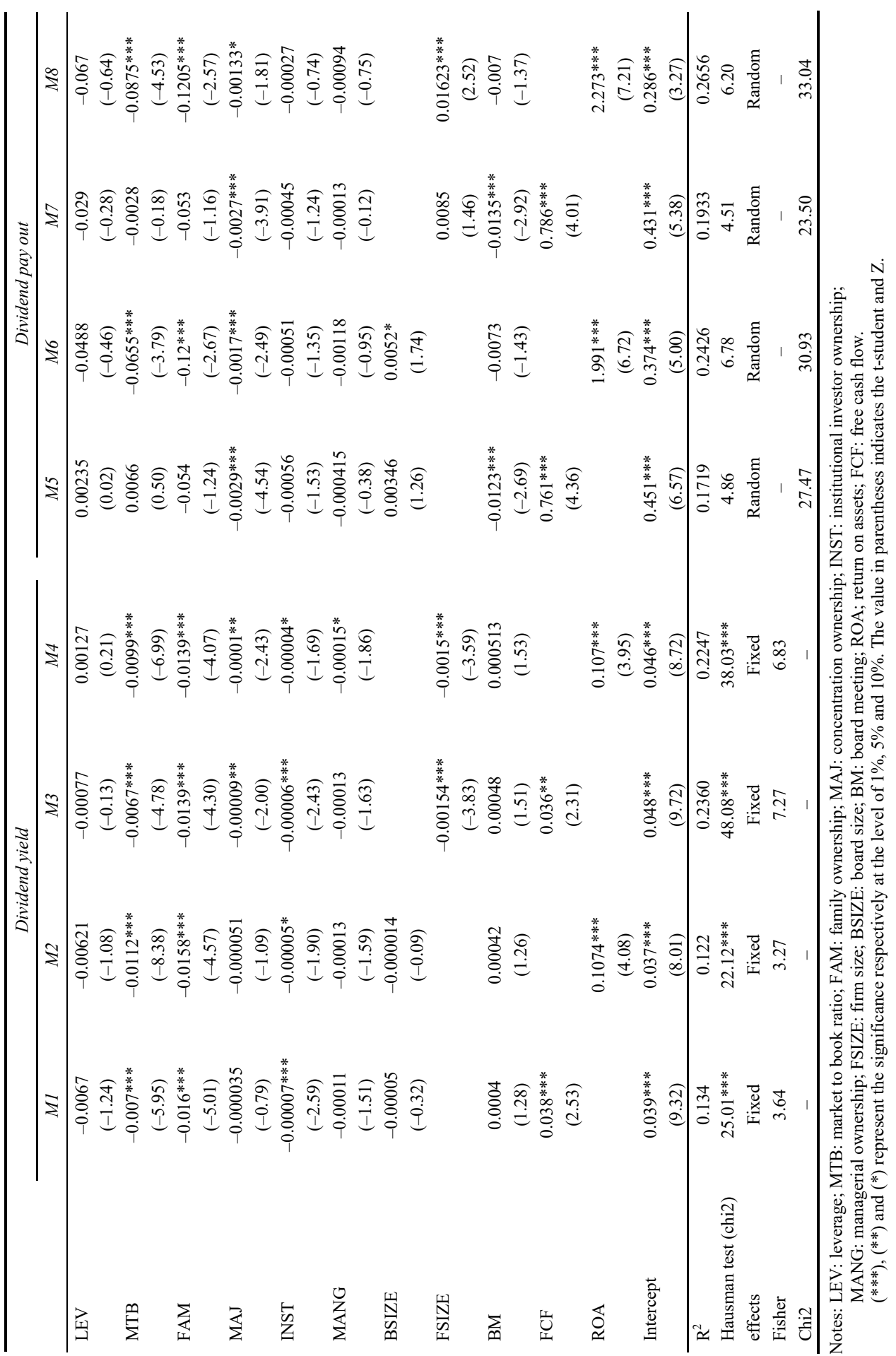


Similarly, we obtained a negative relationship between family ownership and our two dependent variables (dividend yield and dividend pay out). This result is significant at a level of $1 \%$. Listed family firms distribute less than non-family ones. Several studies show a negative influence on the dividend payout of the first shareholder's control level (Mulyani et al., 2016; Hu and Kumar, 2004; Maury and Pajuste, 2002) or the concentration of ownership (Rozeff, 1982; Dempsey and Laber, 1992).

Family firms may have a significantly different dividend policy from non-family companies. If these results are consistent with a substitution dividend payout and monitoring by large shareholders, they may also be evidence of expropriation of minority by a controlling shareholder.

The same result is obtained for the presence of institutional investors. This result confirms the substitution effect between the dividend policy and the participation of institutional investors in the capital of the company. These investors have the tools to control and supervise the executive. Their presence drives the company to distribute less dividends. Finally, our results also show a negative effect of the presence of a majority shareholder on the dividend distribution policy for French companies. Our results are consistent with those of Mancinelli and Ozkan (2006) and Harada and Nguyen (2011). According to Maury and Pajuste (2002), the presence of a shareholder having more than half of the control of the firm has a negative effect on the payout rate.

\section{Conclusions}

In this study, we tried to examine the effect of ownership structure on the dividend distribution policy for French companies. The ownership structure is approximated by four variables, namely managerial, institutional, family ownership. Our results demonstrate the presence of a negative relationship between these variables and the dividend policy. This policy is approximated by two variables namely the distribution rate and yield rate.

Our results indicate the disciplinary effect of dividend policy. This study demonstrates the presence of a substitution between the distribution of dividends and supervision by the ownership structure, and the existence of an expropriation of minorities by a controlling shareholder (family or large shareholder).

Some researchers have discussed the problem of endogenous institutional investors and their relationship with the company's dividend policy. As a future research, it is useful to examine this point using endogenous tests such as the propensity score matching estimator method. This research was conducted in the context of a developed country. It would be very interesting to do a study for emerging countries. This would improve research methodologies adapted by adding specific variables to these countries that can influence the dividend policy (legal system; shareholder's protection, creditor rights). 


\section{References}

Abdullah, N.M.H., Ahmad, Z. and Roslan, S. (2012) 'The influence of ownership structure on the firms dividend policy based Lintner model', International Review of Business Research Papers, Vol. 8, No. 6, pp.71-88.

Afza, T. and Mirza, H.H. (2010) 'Ownership structure and cash flows as determinants of corporate', International Business Research, Vol. 3, No. 3, pp.210-221.

Agrawal, A. and Jayraman, N. (1994) 'The dividend policies of all-equity firms: a direct test of the free cash flow theory', Managerial and Decision Economics, Vol. 15, No. 2, pp.139-148.

Agrawal, A. and Mandeleker, G. (1990) 'Large shareholders and the monitoring of managers: the case of antitakeover charter amendments', Journal of Financial and Quantitative Analysis, Vol. 25, No. 2, pp.143-161.

Aguenaou, S., Farooq, O. and Di, H. (2013) 'dividend policy and ownership structure: evidence from the Casablanca Stock Exchange', GSTF International Journal on Business Review, Vol. 2, No. 4, pp.116-121.

Al-Gharaibeh, M. (2013) 'The effect of ownership structure on dividends policy in Jordanian companies', Interdisciplinary Journal of Contemporary Research in Business, Vol. 4, No. 9, pp.769-796.

Allen, F., Bernado, A. and Welch, I. (2000) 'A theory of dividends based on tax clientele', Journal of Finance, Vol. 55, No. 6, pp.2499-2536.

Alli, K.L., Khan, A.Q. and Ramirez, G.G. (1993) 'Determinants of corporate dividend policy: a factorial analysis', Financial Review, Vol. 28, No. 4, pp.523-547.

Al-Najjar, B. and Kilincarslan, E. (2016) 'The effect of ownership structure on dividend policy: evidence from Turkey', Corporate Governance: The International Journal of Business in Society, Vol. 16, No. 1, pp.135-161.

Balachandran, B., Khan, A., Mather, P. and Theobald, M. (2017) 'Insider ownership and dividend policy in an imputation tax environment', Journal of Corporate Finance, February.

Bebchuk, L.A., Kraakman R. and Triantis, G. (2000) 'Stock pyramids, cross-ownership, and dual class equity: the creation and agency costs of separating control from cash flow rights', in Morck, R.K. (Ed.): Concentrated Corporate Ownership, NBER, University of Chicago Press, USA.

Borokhovich, K., Brunarski, R., Harman, Y. and Kehr, J.B. (2005) 'Dividends, corporate monitors and agency costs', The Financial Review, Vol. 40, No. 1, pp.37-65.

Burkart, M., Gromb, D. and Panunzi, F. (1997) 'Large shareholders, monitoring, and the value of the firm', Quarterly Journal of Economics, Vol. 112, No. 3, pp.693-728.

Charreaux (1997) Le gouvernement de l'Entreprise: Corporate Governance, Théorie et Faits. Economica, p.540.

Chen, C. and Steiner, T. (1999) 'Managerial ownership and agency conflict: a non-linear simultaneous approach', The Financial Review, Vol. 34, No. 1, pp.119-136.

Chen, Z., Cheung, Y-L., Stouraitis, A. and Wong, A.W.S. (2005) 'Ownership concentration, firm performance, and dividend policy in Hong Kong', Pacific-Basin Finance Journal, Vol. 13, No. 4, pp.431-449.

Crane, D.A., Michenaud, S. and Weston, J.P. (2016) 'The effect of institutional ownership on payout policy: evidence from index thresholds', The Review of Financial Studies, Vol. 29, No. 6, pp.1377-1408. 
Dempsey, S.J. and Laber, G. (1992) 'Effects of agency and transaction costs on dividend payout ratios: further evidence of the agency-transaction cost hypothesis', Journal of Financial Research, Vol. 15, No. 4, pp.317-321.

Easterbrook, F. (1984) 'Two agency-cost explanations of dividends', American Economic Review Vol. 74, No. 4, pp.650-659.

Fairchild, R., Guney, Y. and Thanatawee, Y. (2014) 'Corporate dividend policy in Thailand: theory and evidence', International Review of Financial Analysis, Vol. 31, pp.129-151.

Fama, E. (1974) 'The empirical relationship between the dividend and investment decisions of firms', American Economic Review, Vol. 64, No. 3, pp.304-318.

Fernandez, C and Arrondo, R. (2005) 'Alternative internal controls as substitute of the board of directors', Corporate Governance: An International Review, Vol. 13, No. 6, pp.856-866.

Firth, M., Gao, J., Shen, J., and Zhang, Y. (2016) 'Institutional stock ownership and firms' cash dividend policies: evidence from China', Journal of Banking and Finance, Vol. 65, No. 1 pp.91-107.

Gill, S. and Obradovich, D.J. (2012) 'Corporate governance, institutional ownership, and the decision to pay the amount of dividends: evidence from USA', International Research Journal of Finance and Economics, Vol. 97, No. 1, pp.60-71.

Gonzalez, M., Molina, C.A., Pablo, E. and Ross, J.W. (2017) 'The effect of ownership concentration and composition on dividends: evidence from Latin America', Emerging Markets Review, Vol. 30, No. 1, pp.1-18.

Grinstein, Y. and Michaely, R. (2005) 'Institutional holdings and payout policy', Journal of Finance, Vol. 60, No. 3, pp.1389-1426.

Gugler, K. (2003) 'Corporate governance, dividend payout policy, and the interrelation between dividends, R\&D, and capital investment', Journal of Banking and Finance, Vol. 27, No. 7, pp.1297-1321.

Gugler, K. and Yurtoglu, B. (2003) 'Corporate governance and dividend payout policy in Germany', European Economic Review, Vol. 47, No. 4, pp.731-758.

Han, K., Lee S.H. and Suk D.Y. (1999) 'Institutional shareholders and dividends', Journal of Financial and Strategic Decision, Vol. 12, No. 1, pp.53-62.

Harada, K. and Nguyen, P. (2011) 'Ownership concentration and dividend policy in Japan', Managerial Finance, Vol. 37, No. 4, pp.362-379.

Harada, K., and Nguyen, P. (2011) 'Ownership concentration and dividend policy in Japan', Managerial Finance, Vol. 37, No. 4, pp.362-379.

Hausman, J.A. (1978) 'Specification tests in econometrics', Econometrica, Vol. 46, No. 6, pp.1251-1271.

Hirigoyen, G. (1984) Contribution de la connaissance des comportements financiers des moyennes entreprises industrielles et familiales, thèse Université de Bordeaux I.France.

Hofler, R., Elston, J. and Lee, J. (2004) Dividend Policy and Institutional Ownership: Empirical Evidence using a Propensity Score Matching Estimator, Discussion papers on Entrepreneurship, Growth and Public Policy, No. 2004-27.

Holder, M., Langrehr, F.W. and Hexter, J.L. (1998) 'Dividend policy determinants: an investigation of the influences of stakeholder theory', Financial Management, Vol. 27, No. 3, pp.73-82.

Hu, A. and Kumar, P. (2004) 'Managerial entrenchment and payout policy', The Journal of Financial and Quantitative Analysis, Vol. 39, No. 4, pp.759-790.

Izmen, U. (2003) 'Instituting corporate governance in family-owned firms in Turkey', in In Search of Good Directors: A Guide to Building Corporate Governance in the 21st Century, 3rd ed., Chapter 21, pp.323-332, The Center for International Private Enterprise, Washington DC.

Jain, R. (2007) 'Institutional and individual investor preferences for dividends and share repurchases', Journal of Economic and Business, Vol. 59, No. 5, pp.406-429. 
Jensen, G.R., Solbery, D.P. and Zorn, T.S. (1992) 'Simultaneous determination of insider ownership, debt and dividend policies', Journal of Financial and Quantitative Analysis, Vol. 27, No. 1, pp.247-263 [online] http://dx.doi.org/10.2307/2331370.

Jensen, M.C. (1986) 'Agency costs of free cash flow, corporate finance, and takeovers', American Economic Review, Vol. 76, No. 2, pp.323-329.

Jensen, M.C. (1993) 'The modern industrial revolution, exit and failure of internal control systems', Journal of Finance, Vol. 48, No. 3, pp.831-880.

Jensen, M.C. and Meckling, W.H. (1976) 'Theory of the firm: managerial behaviour, agency costs and ownership structure', Journal of Financial Economics, Vol. 3, No. 4, pp.305-360.

Jong D., DeJong, D.V., Hege U. and Mertens, G. (2011) Leverage in Pyramids: When Debt Leads to Higher Dividends, Working Papers, ECGI.

Kim, K., Al-Shammari, H., Kim, B., and Lee, S. (2008) CEO Duality Leadership and Corporate Diversification Behavior, Working Paper, St. Cloud State University, St. Cloud, Minnesota.

Kouki, M. and Guizani, M. (2009) 'Pouvoir de vote des actionnaires et politique de dividende: Étude empirique sur les entreprises Tunisiennes cotées', Revue du financier, Nos. 178-179, pp.109-128.

La Porta, R., Lopez-de-Silanes, F., Shleifer, A. and Vishny, R. W. (2000) 'Agency problems and dividend policies around the world', Journal of Finance, Vol. 55, No. 1, pp.1-33.

Li, K. and Zhao, X. (2008), 'Asymmetric information and dividend policy', Financial Management, Vol. 37, No. 4, pp.673-694.

Lie, E. (2000) 'Excess funds and agency problems: an empirical study of incremental cash disbursements', Review of Financial Studies, Vol. 13, No. 1, pp.219-248.

Lin T.J., Chen, Y.P. and Tsa, H.F. (2017) 'The relationship among information asymmetry, dividend policy and ownership structure', Finance Research Letters, Vol. 20, No. 1, pp.1-12.

Mancinelli, L. and Ozkan, A. (2006) 'Ownership structure and dividend policy: evidence from Italian firms', The European Journal of Finance, Vol. 12, No. 3, pp.265-282.

Maury, C.B. and Pajuste, A. (2002) Controlling Shareholders, Agency Problems, and Dividend Policy in Finland, Working Paper, Swedish School of Economics and Business Administration [online] http://lta.hse.fi/2002/1/lta_2002_01_a1.pdf.

McConnell, J. and Servaes, H. (1990) 'Additional evidence on equity ownership and corporate value', Journal of Financial Economics, Vol. 27, No. 2, pp.595-612.

Miller, M.H. and Modigliani, F. (1961) 'Dividend policy, growth, and the valuation of shares', Journal of Business, Vol.34, No. 4, pp.411-433 [online] http://dx.doi.org/10.1086/294442.

Miller, M.H. and Rock, K. (1985) 'Dividend policy under asymmetric information', Journal of Finance, Vol. 40, No. 4, pp.1031-1051.

Moh'd, M.A., Perry, L.G. and Rimbey, J.N. (1995) 'An investigation of the dynamic relationship between agency theory and dividend policy', Financial Review, Vol. 30, No. 2, pp.367-385.

Mollah, A.S., Keasey, K. and Short, H. (2007) The Influence of Agency Costs on Dividend Policy in an Emerging Market, Working paper, Leeds University Business School.

Morck, R., Shleifer, A. and Vishny, R. (1988) 'Management ownership and market valuation: an empirical analysis', Journal of Financial Economics, Vol. 20, No. 1, pp.293-315.

Mulyani, E., Singh, H. and Mishra, S. (2016) 'Dividends, leverage, and family ownership in the emerging Indonesian market', Journal of International Financial Markets, Institutions and Money, Vol. 43, No. 1, pp.16-29.

Naceur, S.B., Goaied, M. and Belanes, A. (2006) 'On the determinants and dynamics of dividend policy', International Review of Finance, Vol. 6, No. 1, pp.1-23.

Nawaiseh, A. (2013) 'Dividend policy and ownership structure: an applied study on industrial companies in Amman Stock Exchange', Journal of Management Research, Vol. 5, No. 2, pp.83-106. 
Pablo, E. and Gonzalez, M. (2010) 'Dividend policy and ownership structure in Latin America', Annual Meeting of the BALAS Annual Conference, ESADE, Barcelona, Spain.

Pound, J. (1988) 'Proxy contests and the efficiency of shareholder oversight', Journal of Finance Economics, Vol. 20, No. 1, pp.237-265.

Renneboog, L.D.R. and Trojanowski, G. (2005) Control Structures and Payout Policy, Discussion Paper, CentER, Tilburg, Finance, Vol. 2005-61.

Rozeff, M.S. (1982) 'Growth, beta and agency costs as determinants of dividend payout ratios', Journal of Financial Research, Vol. 5, No. 2, pp.249-259.

Sawicki, J. (2005) 'Changes in corporate governance and dividend policy prompted by the Asian financial crisis', 4th Finance Conference, the Portuguese Finance Network, Portugal.

Sharif, S.J.S., Salehi, M. and Bahadori, H. (2010) 'Ownership structure of Iranian evidence and payout ratio', Asian Social Science, Vol. 6 No. 7, pp.36-42.

Shleifer, A. and Vishny, R. (1986) 'Large shareholders and corporate control', Journal of Political Economy, June, Vol. 94, pp.461-488.

Shleifer, A. and Vishny, R.W. (1997) 'A survey of corporate governance', Journal of Finance, Vol. 52, No. 2, pp.737-783.

Short, H. (1994) 'Ownership, control, financial structure and the performance of firms', Journal of Economic Survey, Vol. 8, No. 3, pp.203-249.

Short, H., Zhang, H. and Keasey, K. (2002) 'The link between dividend policy and institutional ownership', Journal of Corporate Finance, Vol. 8, No. 2, pp.105-122.

Stouraitis, A. and Wu, L. (2004) The Impact of Ownership Structure on the Dividend Policy of Japanese Firms with Free Cash Flow Problem, AFFI December Meeting.

Truong, T. and Heaney, R. (2007) 'Largest shareholder and dividend policy around the world', Quarterly Review of Economics and Finance, Vol. 47, No. 5, pp.667-687.

Truong, T. and Heaney, R. (2007) 'Largest shareholder and dividend policy around the world', The Quarterly Review of Economics and Finance, Vol. 47, No. 5, pp.667-687.

Warrad, L., Suzan A., Khriasat, O. and Al-Sheikh, I. (2012) 'The effect of ownership structure on dividend payout policy: evidence from Jordanian context', Int. J. Economics and Finance, Vol. 4, No. 2, pp.187-195.

Wei, Z., Wu, S., Li, C. and Chen, W. (2011) 'Family control, institutional environment and cash dividend policy: evidence from China', China Journal of Accounting Research, Vol. 4, pp.29-46.

Wie, G., Zhang, W. and Xiao, J.Z. (2003) Dividend Policy and Ownership Structure in China, Working Paper, SRNN, Series No. 463924

Yarram, S.R. (2011) 'Board characteristics and dividend ratio: Australian evidence', Economics and Public Ratio, pp.1-21, 4th International Business and Social Science Research Conference, World Business Institute Australia, Melbourne, Victoria, Australia [online] https://www.wbiconpro.com/334-Subba.pdf.

Yoshikawa, T. and Rasheed, A.A. (2010) 'Family control and ownership monitoring in family controlled firms in Japan', Journal of Management Studies, Vol. 47, No. 2, pp.274-295.

\section{Notes}

1 The SBF 120 (Société des Bourses Françaises 120 Index) is a French stock market index. The index is based on the 120 most actively traded stocks listed in Paris.

2 The Autorité des marchés financiers (AMF) (English: 'Financial Markets Regulator') is the stock market regulator in France. 